Результаты проведения специальных пневмоиспытательных исследований подтверждают, что при отработке подкарьерных запасов под водным объектом под защитой предохранительного целика расчетной мощностью 25 м и толщей уже отработанных и заложенных очистных слоев сохраняются безопасные и благоприятные условия ведения горных работ. Опасность прорыва воды и пульпы в зону ведения горных работ в настоящее время при существующей технологии ведения очистных работ и обеспечении сохранности подкарьерных горных выработок отсутствует.

$$
* * *
$$

1. Баренблатт Г.И., Ентов В.М., Рыжик В.М. Теория нестационарной фильтрации жидкости и газа. М., Недра, 1972. С. 288.

2. Колганов В.Ф., Акишев А.Н., Дроздов А.В. Геолого-геологические особенности коренных месторождений алмазов Якутии. Мирный, Якутнипроалмаз, 2013. С. 568.

\title{
Иванова Е.Ю.
}

К вопросу об изученности распределения пищевых группировок зообентоса в полярных областях мирового океана

Московский государственный областной университет

(Россия, Мьıтищи)

doi: 10.18411/lj-04-2021-67

\section{Аннотация}

Рассмотрены результаты изученности распределения донной фауны в Северном Ледовитом и Южном океанах. Произведено картирование и описание более 3000 точек находок представителей различных пищевых группировок (детритофаги, сестонофаги, хищники) зообентоса в границах полярных областей Мирового океана. Выявлены доминирующие пищевые группировки и оценена полярная асимметрия в распределении донной фауны по дну полярных областей Северного Ледовитого и Южного океанов.

Ключевые слова: донная фауна, зообентос, детритофаги, сестонофаги, хищники.

\section{Abstract}

The results of the study of the distribution of bottom fauna in the Arctic and Southern oceans are considered. The mapping and description of more than 3000 points of finds of representatives of various food groups (deposit feeders, seston feeders, predators) of zoobenthos within the boundaries of the polar regions of the World Ocean was carried out. The dominant food groups were identified and the polar asymmetry in the distribution of bottom fauna over the bottom of the polar regions of the Arctic and Southern Oceans was estimated.

Keywords: bottom fauna, zoobenthos, detritus feeders, seston feeders, predators.

Геоэкологическая зависимость распределения ресурсов пищевых группировок донных беспозвоночных в полярных океанах актуальна с научной и практической точек зрения, поскольку донные морские организмы представляют собой важнейший компонент и трофическое звено биосферы. Они играют огромную роль в круговороте химических веществ в океане, формировании продуктивности его вод, изменении условий морской среды. Районы скопления донных животных указывают на концентрации морских организмов высших трофических уровней. Кроме того, некоторые беспозвоночные сами являются промысловыми видами. 
Первые оценки количественного и качественного распределения фауны по дну полярных областей Мирового океана были выполнены во второй половине XX столетия рядом ученых: Л.А. Зенкевичем, Г.М. Беляевым, А.А. Нейман, Н.Г. Виноградовой, Е.П. Турпаевой, 3.А. Филатовой, Т.С. Лукьяновой и другими. Огромный фактический материал, накопленный за последнее время, представляет фундаментальную базу данных по зообентосу.

Изучение геоэкологического распределения донных животных в Северном Ледовитом океане по трофическому принципу велось и ведется шире, чем в Южном океане.

По Северному Ледовитому океану рядом ученых в период с 1946 по 2021 гг. исследованы районы: евразийского, амеразийского, евроамерийского и Центрального Арктического суббассейнов. По Южному океану за тот же период исследованы районы: западной и восточной Антарктики, а также периферии дна Южного океана [1].

Систематизация и анализ имеющихся данных по точкам находок представителей донной фауны различных трофических группировок позволили составить картосхемы изученности геоэкологического распределения зообентоса по способу питания в полярных областях океанов.

\section{Объект исследования}

Объектом исследования является трофическая структура зообентоса. Предметом исследования является оценка изученности распределения зообентоса с различным типом питания в полярных областях.

Научная новизна и практическая значимость работы состоит в том, что с помощью комплексной обработки фактического материала (сбор и анализ информации опубликованных материалов, наложение и совмещение карт распределения биомассы зоопланктона, Сорг., гранулометрического и химического состава донных отложений, гидрологических данных с данными по биомассе зообентоса) и использования картографического метода исследования были систематизированы данные по распределению донных беспозвоночных с разным типом питания и составлены картосхемы изученности геоэкологического распределения зообентоса по способу питания в полярных областях океанов [2].

\section{Материалы и методы исследования}

Картосхемы изученности геоэкологического распределения зообентоса по способу питания в полярных областях океанов создавались по следующей методике:

За рабочую основу картосхем была взята геодезическая основа контурных карт Антарктики в масштабе 1:55 000000 и Арктики в масштабе 1:25 000000 (рис.1, 2).

Имеющийся материал по распределению зообентоса систематизировался, исходя из количественного и качественного состава донных животных, поскольку картосхемы изученности несут на себе двойную нагрузку. Во-первых, это точечные объекты, которые показывают охват территории с имеющимися конкретными данными по местонахождению отдельных представителей донной фауны. Во-вторых, каждая точка показывает трофическую принадлежность представителей зообентоса на отдельных территориях.

Информация на картосхеме изученности отражается значковым способом (кружочками - хищники, квардратами - сестонофаги, треугольниками - детритофаги).

Для этого имеющийся материал (в графическом, статистическом, текстовом вариантах) классифицировался на 3 группы: хищники, детритофаги и сестонофаги. По имеющимся координатам (описанию), условные обозначения наносились на картосхемы Северного Ледовитого и Южного океанов. 


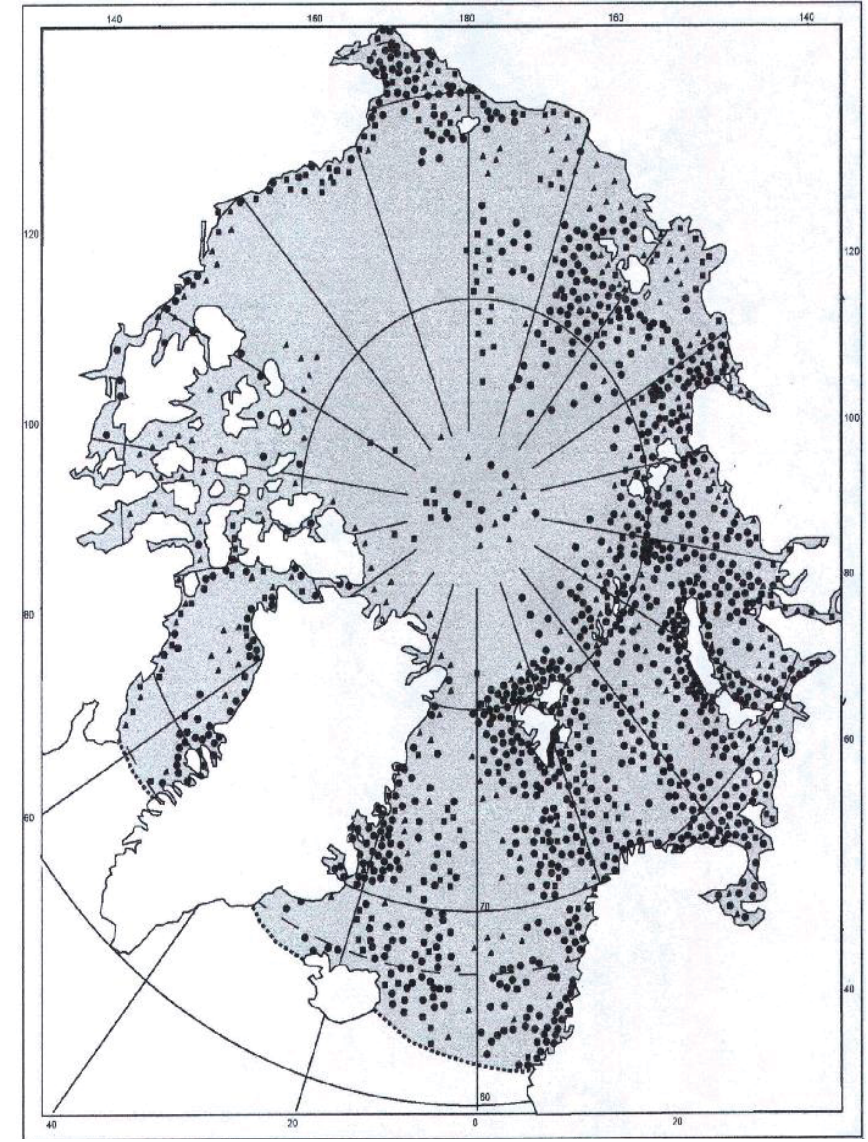

Рис. 1. Изученность зообентоса Северного Ледовитого океана по литературным источникам

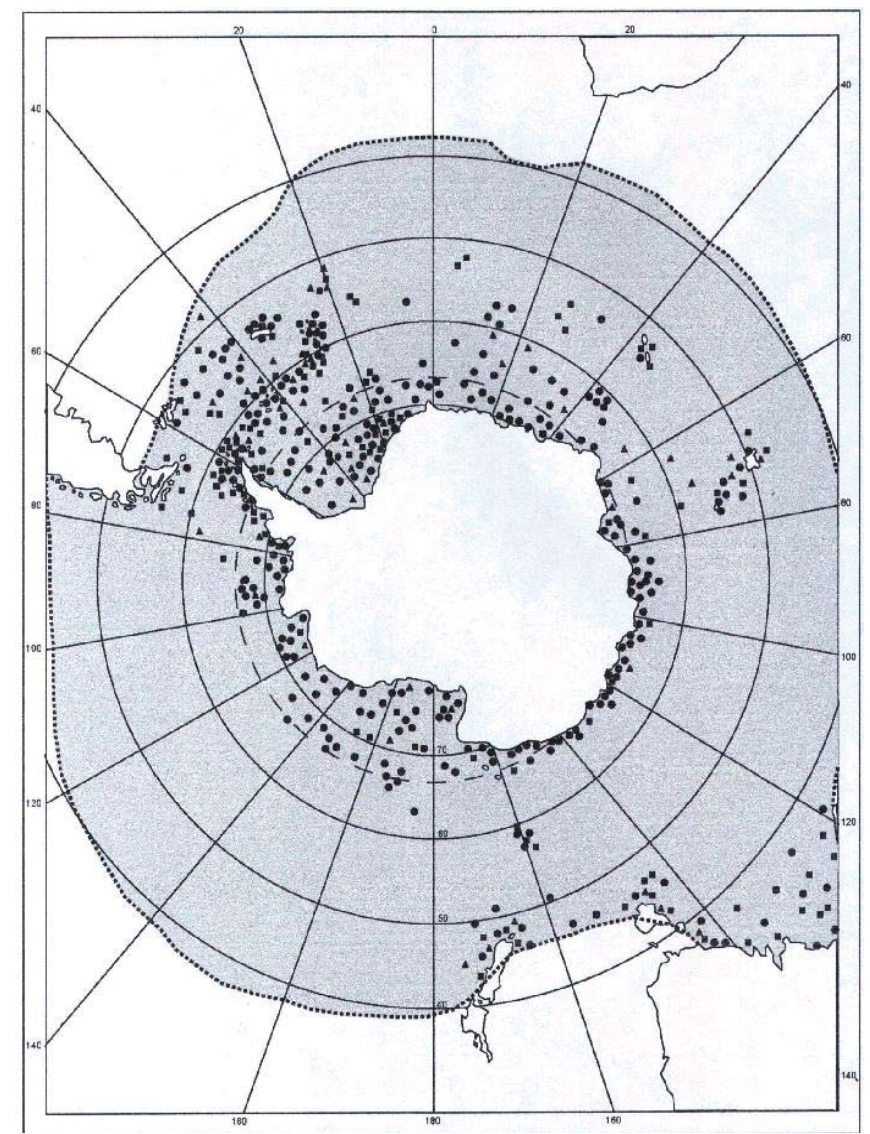

Рис. 2. Изученность зообентоса Южного океана по литературным источникам 
Немаловажно отметить внемасштабность условных знаков, поскольку, в большинстве случаев, данные нескольких источников отражались одной точкой. Это объясняется тем, что на мелкомасштабной карте не представляется возможным отразить реальное количество данных значковым способом. Тем не менее, в сумме на картосхемах изученности литературных источников полярных океанов зафиксировано более 3000 точек.

\section{Результаты и их обсуждение}

Построение данных картосхем было первым шагом к оценке биомассы донной фауны по способу питания, поскольку именно эти данные послужили основой для дальнейшей экстраполяции и интерполяции имеющегося фактического материала.

Созданные картосхемы показывают объем статистического материала по донным животным, как по конкретным территориям, так и по океанам в целом (более 3 000 точек). Наибольшее количество фактических данных имеется по атлантическому и евразиатскому секторам Северного Ледовитого океана. Эти области в настоящее время являются наиболее изученными, в первую очередь, российскими учеными (рис. 1, 2). Менее изученными оказались области Центрального Арктического и Амеразийского суббассейнов. Практически отсутствует информация на глубоководные котловины центральной части Северного Ледовитого океана.

В Южном океане наибольшее количество информации приходится на центральную часть океана, опоясывающую Антарктиду и море Скотия, а так же на индо-австралийский сектор. Периферия же характеризуется минимальным объемом информации.

Трофическая принадлежность зообентоса, отраженная на картосхемах изученности позволяет сделать выводы по распространению гидробионтов [3]. Так, максимальное количественное распространение в обоих океанах наблюдается у представителей хищников, что объясняется практически повсеместным наличием кормовой базы, представленной различными территориям прибрежных мелководий. Этому способствуют высокая концентрация органического вещества, осаждающегося в тонкой фракции донных осадков, выстилающих глубоководные области дна. Максимальное поступление биогенных элементов в этих областях связано с зонами дивергенции. Сестонофаги наблюдаются в прибрежных районах, на мелководьях, материковых склонах и склонах котловин. Данный факт объясняется присутствием на этих территориях жестких грунтов и придонных течений, а также высокой скорости седиментации.

Прибрежные части шельфовой зоны полярных океанов с распространением жестких грунтов населены преимущественно сестонофагами [4,5]. В этих областях присутствуют как подвижные, так и неподвижные сестонофаги. Доминирование первых приурочено к областям ледового разноса и размыва коренных пород дна. Неподвижные сестонофаги имеют максимальное сосредоточение в зонах действия сильных придонных течений и активных волновых процессов. Центральные части шельфа вплоть до материкового склона отмечены доминированием детритофагов, на отдельных территориях - с незначительным количеством сестонофагов. Материковый склон в центральной части заселен детритофагами, бровка и подножье являются зонами перекрытия сестонофагов и детритофагов, поскольку являются областями сноса песчаной и пелитовой фракций грунта и действия подводных течений [6,7]. Ложе океанов покрыто тонкозернистыми грунтами и являются областью распространения детритофагов. Подводные возвышенности заселены сестонофагами (распространены преимущественно крупноалевритовые и песчаные грунты, промываемые течениями). Верхние части склонов глубоководных котловин населены преимущественно детритофагами, в меньшей степени сестонофагами, поскольку выстланы мелкозернистыми грунтами и характеризуются низкой степенью седиментации. Дно котловин, как правило, практически не заселяется, поскольку содержание 
органического вещества в осадках и придонном слое минимальное. В Северном Ледовитом океане донная фауна не опускается ниже 3500м, в Южном - ниже 4500м.

\section{Заключение:}

1. Изучение распределения донной фауны в полярных океанах активно ведётся российскими и зарубежными исследователями с 50-х годов прошлого столетия и по настоящее время.

2. Распределение трофических группировок в полярных областях азонально. Наиболее оптимальными условиями существования характеризуются шельфовые районы, то есть периферия в Арктическом бассейне и центральные части - в Антарктическом.

3. В количественном распределении трофических группировок зообентоса в полярных областях наблюдается асимметрия. Наибольшие количественные значения детритофагов, сестонофагов и хищников в Северном Ледовитом океане приурочены к периферии бассейна, в Южном - к центральным частям океана.

4. Донная фауна периферии Северного Ледовитого океана представлена преимущественно сестонофагами, центральная часть океана занята тонкодисперсными фракциями грунта, которая заселена преимущественно детритофагами.

5. Донная фауна периферии Южного океана представлена преимущественно детритофагами, центральная часть океана покрыта осадками крупных фракций и занята преимущественно сестонофагами.

$$
* * *
$$

1. Иванова Е.Ю. Геоэкологическое распределение ресурсов пищевых группировок зообентоса полярных областей океанов. Диссертация на соискание ученой степени кандидата географических наук. - М.: МГОУ, 2005, 174c.

2. Иванова Е.Ю. Условия распределения зообентоса в полярных областях Мирового океана// "География в школе XXI века", 2005, №7, с. 38-40.

3. Лукьянова Т.С. Закономерности географического распределения ресурсов донной фауны по океанам. Автореф. докт. дис. - М.: 2003, с.30-31.

4. Матишов Г.Г., Бердников С.В., Жичкин А.П., Макаревич П.Р., Дженюк С.Л., Кулыгин В.В., Яицкая Н.А., Поважный В.В., Шевердяев И.В., Третьякова И.А., Цыганкова А.Е. Атлас климатических изменений в больших морских экосистемах северного полушария (1878-2013). Ростов-на-Дону, 2014.

5. Матишов Г.Г., Дженюк С.Л., Моисеев Д.В. Климат и большие морские экосистемы Арктики.// Вестник Российской академии наук, 2017, Т.87, №2, с. 110-120.

6. Морозов Е.Г., Флинт М.В., Спиридонов В.А., Тараканов Р.Ю. Программа комплексных экспедиционных исследований экосистемы Атлантического сектора Южного океана (декабрь 2019 - март 2020 г.), Океанология, 2019, Т. 59, №6, с. 1086-1088.

7. Морозов Е.Г., Спиридонов В.А., Молодцова Т.Н., Фрей Д.И., Демидова Т.А., Флинт М.В. Исследования экосистемы атлантического сектора Антарктики (79-й рейс научноисследовательского судна «Академик Мстислав Келдыш»), Океанология 2020, Т.60. № 5, с. 823825.

Кубайдуллина У.А., Старостина О.В., Долгоносов В.Н. Георадарный мониторинг на Васильковском карьере AO «Altyntau Kokshetau»

\section{Аннотация}

В статье представлены результаты георадарного мониторинга состояния прибортового массива на Васильковском карьере.

Ключевые слова: мониторинг, радар, геотехнический риск, когерентность, тренд деформации. 